\title{
Current Tendencies of Judicial Review as Reflected in the New Hungarian Code of Administrative Court Procedure ${ }^{1}$
}

\author{
Krisztina F. Rozsnyai \\ Eötvös Loránd University Budapest, Faculty of Law, Department of Public \\ Administration, Hungary \\ rozsnyaik@ajk.elte.hu \\ https://orcid.org/0000-0002-1494-5051
}

Received: 11. 7. 2018

Accepted: 23. 10. 2018

\section{ABSTRACT}

The continuing expansion of judicial review of administrative actions, as seen throughout Europe, led to the engulfment of the administrative judiciary towards the end of the last century. Review within a reasonable timeframe is hard to grant for this reason: the tensions between lawfulness and efficiency are amplified. The answers given to alleviate this tension raise questions that lie at the heart of the system of checks and balances between public administration and the judiciary. This article aims to present some of respective tendencies. To concretise these tendencies, the article analyses some relevant solutions given by the very new code of administrative court procedures, the Hungarian Act No. I of 2017. The most important elements of the regulation of procedures for judicial review of administrative action are provided in a dogmatic and a comparative perspective showing the changes of rules and/or their interpretation through the judiciary. Thus, major challenges regarding the present understanding of the doctrine of separation of powers are emphasised. The most significant elements of the new Hungarian regulation are presented in a coherent system, which also gives insight on the codificational considerations. Legislation and jurisprudence must deal with the highlighted aspects in any national and in EU legal systems alike.

Keywords: administrative judicial review, court procedure, codification, Hungary, Europeanisation, interim relief

1 This article is a result of the project No. 112550 "New tendencies in the regulation of the single European market and its effects on the organisation and functioning of public administration", supported by the Hungarian Scientific Research Fund (OTKA). 


\section{Introduction}

The creation of administrative justice in Hungary dates back to 1883, when, as a provisional first step, the Royal Court of Finances was established leaning on the Austrian organisational model. The intended transformation of this model into a two instance system failed: only the Hungarian Royal Administrative Court could be established in $1896 .{ }^{2}$ The second step of creating first instance administrative tribunals in spite of continuous reform projects never followed. The Royal Administrative Court was abolished in 1949. Since then administrative court procedures were conducted by ordinary (civil) courts with few and weak competences. ${ }^{3}$ In 1991, the possibility of access to court was broadened, but other elements of court procedure and court organisation remained unchanged. It was only in 2013 that first instance "administrative and labour courts" started to function. ${ }^{4}$ As an important step of the gradual restoration of the autonomy of administrative justice, the Code of Administrative Court Procedure (CACP) was promulgated on 1 March 2017 as Act I of 2017 and entered into force on 1 January 2018.

The codification of administrative court procedure rules was centred on the principle of effective judicial protection. In the process of codification, the Hungarian legislature had to find answers to questions touching on the essence of the doctrine of separation of powers in order to create a set of rules which grant both the timeliness and effectivity of judicial review as the most important control of the legality of administrative action.

The answers given raise questions which lie at the heart of the principle of separation of powers. Of course, this constitutional principle is not static; it needs to evolve together with the developments of society and economy. As access to administrative courts gets broader, different restraints are incorporated into the system of judicial review, partly by the judiciary itself, partly by the legislation. The same way, as the powers of courts increase, preclusion rules emerge from both sides.

This paper identifies some questions regarding checks and balances and the connected tendencies, and presents the answers given by the Hungarian legislature in the CACP. This code is built not only on the jurisprudence, which has developed since 1991, when judicial review was quasi reintroduced as a general possibility according to the ruling No. 32/1990. (XII 22.) of the Consti-

2 With an enumerative model of access to court though, and the competence to even reform administrative acts after a written procedure.

3 Access to court was only granted against some authoritative administrative decisions of minor importance and courts generally could merely annul them. Since 1972, administrative court procedures have been regulated as a special civil procedure within the Act on Civil Procedure Rules.

4 For the historical development of administrative justice in Hungary and the characteristics of organisation and procedure of the Hungarian Royal Administrative Court, as well as the further debates and developments see Patyi, A.: Közigazgatási bíráskodásunk modelljei, 2002, Budapest: Logod, or F. Rozsnyai, K., \& 43 Geschichte der Verwaltungsgerichtsbarkeit in Ungarn, in Sommermann, K.-P. and Schaffarzik, B., 2018, Handbuch der Geschichte der Verwaltungsgerichtsbarkeit in Deutschland und Europa., BerlinHeidelberg: Springer, pp. 1570-1576. 
tutional Court, but also on the solutions of other European countries and present European trends. Thus, the methods used to present the solutions form a dogmatic and comparative analysis of the legislative and judicial answers given to some current problems of administrative justice in Europe. Due to a limitation of space, the paper does not contain in-depth case studies, but only refers to their relevance.

\section{Access to justice}

\subsection{Widening the scope of judicial review}

One of the most important international trends regarding judicial review is the expansion of the possibility to request judicial review of administrative action. In Hungary, it was principally only formal administrative acts deciding single cases that were apt for judicial review. In the last decade though, there have been some developments in this field. Since 2005, it is possible to sue the administration because of "silence d'administration" (failure to act) in formal administrative procedures on application. Access to court has opened up in relation to some decisions outside the realm of authoritative administrative action, e.g. against disciplinary decisions of professional chambers, or of school directors. A culmination of this development, the greatest novelty of the CACP is the broad scope of application guaranteed by the general rule of access to court formulated in Art. 4 (1). According to this, all administrative activity can be the subject of an administrative dispute. The notion of administrative activity is formulated widely as "an act regulated under administrative law and taken by an administrative organ with the aim to alter the legal situation of an entity affected by administrative law or resulting in such an alteration, or the lawfulness of the administrative organ's failure to carry out such an act".

Important developments due to the broadened scope of judicial protection are on the one hand the contestability of omissions outside the field of authoritative decisions, and on the other hand the reviewability of "normative acts of non-legislative nature" issued by administrative organizations, which are not legislative instruments. These latter general acts can primarily be brought before court in connection with individual acts which apply these regulations. This is also in line with the developments regarding soft law instruments in the jurisprudence of national courts, and that of the ECJ (Kovács et al., 2016), as well as with trends of judicial protection against the norm-setting powers of self-governing bodies (Hoffman and Rozsnyai, 2015). In Hungary, control over the legality of legislative instruments belongs within the competences of the Constitutional Court, with the exception of local government decrees and normative decisions (Fábián and Hoffman, 2014, p. 348). Competences in connection with controlling the legality of local government norm-setting were transferred to the Hungarian Supreme Court (now Kúria) from the Constitutional Court, under the new constitution in 2011. The CACP fills the previous lack of procedural regulation of these procedures through a separate chapter, whose regulations take into due account the twofold, constitutional and administrative nature of these procedures (Chapter XXV). 
To set clear some dogmatic questions and hereby foster dogmatic permeation, the CACP contains supplementary dispositions to the general rule of Art. 4 (1). They either describe the notions used by the general rule or clarify some of its borders. So, for example, Art. 4 (4) takes some definitory burden off the jurisprudence and at the same time aims to foster dogmatic penetration by referring to the "political question doctrine" and the findings of organisation theory. It states that no administrative dispute shall take place "a) concerning government activities, in particular with respect to national defence, aliens policing and foreign affairs, b) concerning the lawfulness of an ancillary administrative act serving the purpose of implementing an administrative act, c) between parties in hierarchical or managerial legal relationships, unless otherwise provided by an Act."

To help the interpretation of the notion of administrative action, Art. 4 (2) states that legal disputes stemming from administrative contractual or civil service relationships also qualify as administrative disputes. This should hinder competence conflicts with civil and labour courts. Art. 4 (3) also assists with interpretation, listing some forms of administrative action: "a) single case (individual) decisions; b) administrative measures; c) general acts of nonlegislative nature and d) administrative contracts".

The same logic of aiding interpretation is underlying the explanatory norms of Art. 4 (7), which inter alia define the notions of administrative organ and administrative contract. Administrative organ means "a) an organ of state administration and its organisational unit or entity vested with independent functions and powers, b) the representative body of a local government and its organ, c) the representative body of a national minority self-government and its organ, d) a statutory professional body, an institute of higher education and its official or organ vested with independent functions and powers, and e) any other organisation or person authorised by the law to carry out administrative acts." The decision to define the notion of administrative contracts is the result of the judiciary's failure to address this definitory problem in the last decade (Barabás-Nagy, 2010): the civil branch of the Supreme Court made it practically impossible for administrative judges to support the previous efforts of first instance courts to evolve a material definition for administrative contracts. According to the CACP, administrative contract means "a contract or an agreement concluded by and between Hungarian administrative organs to perform a public function, as well as contracts defined as such by an Act or government decree." The CACP thus puts the burden of identifying administrative contracts partly on the legislator, but also makes room for jurisprudence through the broad notions of administrative organ and public function.

These explanatory paragraphs all deliberately use notions or phrases, which are somewhat vague in order not to hinder their autonomous interpretation through the judiciary and to intensify the dogmatic sensitivity of administrative justice. Flexibility is very important to guarantee access to administrative courts amidst the rapid developments of administrative action. The 
broad scope entails a set of actions. Thus, as a result of the general rule in Art. 4, the CACP lists in Art. 38 the types of actions which may be brought to court. Following from this, the court may be requested to set aside, annul or amend an administrative act (contestation action), but also to establish that an administrative act failed to be performed (omission action), to prohibit the performance of an administrative act (prohibition action), to order that an obligation arising from an administrative relationship be fulfilled (mandatory action), to order that the damage caused in respect of an administrative contractual relationship or administrative relationship be compensated (mandatory action for compensation), or finally to establish an infringement caused by administrative activity or to establish another relevant fact from the perspective of the administrative relationship (declaratory action). The typology of actions in turn underlies the twofold structure of the code: of the six parts of the CACP, the first four parts containing the general rules are modelled for contestation actions, while the fifth part regulates special procedures. ${ }^{5}$ In this twofold structure, the set of actions finds its counterpart in the various types of judgments upholding a claim regulated in Part III, as well as among the rules of special administrative court procedures contained by the fifth part of the CACP.

\subsection{Standing: protection of subjective rights and interests or control of legality of administration?}

Access to courts depends not only on the scope of judicial review, but also on that of standing. Who is entitled to bring a case before court? Only persons directly affected in their rights, or also persons having legally protected interests, or even persons not having such a close link to the case? The notion of the interested public gains importance and affects the present system of checks and balances through the penetration of collective litigation in the field of judicial review. Questions of standing arise anew, which make it necessary to revisit the basic dilemma regarding the function of administrative jurisdiction, already addressed at its creation: „Rechtsschutz oder Verwaltungskontrolle?" The answers given certainly form our understanding of the principle of separation of powers. Originally this was the basic difference between the two main German models of administrative jurisdiction, the Prussian and the Baden model (Hufen, 2013, p. 29), as well as between the later German and the French model. The principles of rule of law and separation of powers require that judicial review should aim not only to protect subjective rights but also to control the administration - i.e. the protection of legality in cases where there is no prejudice caused to concrete persons' rights or legally

5 Here we find chapters for omission actions, mandatory actions, supervisory actions (actions submitted by the legal supervisory organ) against a statutory professional body, and for norm-control actions against local self-governments, as well as a chapter on simplified procedures, the procedure to enforce compliance with a judgment ordering a new procedure or establishing failure to act, and the procedure for designing the competent administrative organ (in the case of a dispute concerning material competence in administrative procedures). Chapter six contains the final provisions, such as entry into force, transitional provisions, and authorisations for government-delegated rulemaking. 
protected interests, as well as in cases where the plaintiff does not contest grave illegalities of the administrative action. The concurrence of models is due to this double function: the question, which one should dominate the system has frequently arisen in the past and arises again at present with the strengthening of civil society. This double function of tribunals is guaranteed by various means and in different ways in national legal systems. Besides the principle of officiality and the ex officio duties and/or authorisations of tribunals flowing from it, the granting of standing to entities serving the protection of public interest and/or human rights is of ever growing importance.

The Directive 2009/22/EC of the European Parliament and of the Council of 23 April 2009 on injunctions for the protection of consumers' interests, later the recommendation of the European Commission of 11 June 2013 on common principles for injunctive and compensatory collective redress mechanisms in the Member States concerning violations of rights granted under Union Law (2013/396/EU), as well as the new proposal of the European Commission of 11 April 2018 for a Directive of the European Parliament and of the Council on representative actions for the protection of the collective interests of consumers [COM(2018) 184 final] try to enhance these possibilities, too. Although centred on private court procedures, mostly on compensation actions and injunctions in this field, these actions can also emerge in administrative court procedures.

The jurisdiction of the ECJ in relation to administrative court procedures clearly fosters the possibility of collective litigation, too. For now, we will only mention the cases connected to the institution of environmental impact assessment (EIA). Perhaps the most evident "battle" in this field was that against Germany, which resulted in a Commission action before the ECJ against Germany for failing to fulfil its obligations under EU law, the European Commission v Federal Republic of Germany case (C-137/14, EU:C:2015:683). As its forerunners, like "Trianel" - Bund für Umwelt und Naturschutz Deutschland, Landesverband Nordrhein-Westfalen (C-115/09, EU:C:2011:289) and Gemeinde Altrip and Others (C-72/12, EU:C:2013:712), this case concerned access to justice and more precisely the scope of the right of access to a review procedure before a court to challenge the legality of decisions, acts or omissions relating to public participation in decision-making in environmental matters. We could also mention cases against other member states, which all dealt with certain aspects of the possibility for the interested public to take part in administrative procedures, including to request judicial review of the decisions brought in such procedures [e.g. Abraham and others (C-2/07, EU:C:2008:133); Djurgården-Lilla Värtans Miljöskyddsförening (C-263/08, EU:C:2009:631); Commission v Spain (C404/09, EU:C:2011:768); Lesoochranárske zoskupenie I. (C-240/09, EU:C:2011:125); Salzburger Flughafen (C244/12, EU:C:2013:203,); Lesoochranárske zoskupenie II. (C-243/15, EU:C:2016:838)]. Whereas previously there was an additional requirement that the procedural error must affect a 'substantive legal position' to which the applicant is entitled, now procedural provisions have to confer independently enforceable procedural positions on persons affected by a project subject to an EIA. 
Continuing the tendency of Europeanisation, the CACP grants various organisations standing to bring a representative action. Administrative organs not taking part in the realisation of the administrative action, but having powers affected by the administrative action are empowered to bring representative actions. In reminiscence somewhat of soviet times, the public prosecutor (or prosecution service) also has standing, if its "notice for legality" expired without yielding any result, because it was not followed by the administrative organ.

The CACP also makes it possible for NGOs to bring representative actions, if a special law allows for this. Just as the Recommendation sets out, these NGOs need to have a non-profit making character, and a direct relationship between the main objectives of the entity and the rights claimed to have been violated is required for standing. Sufficient capacity is guaranteed by the requirement of at least one year of previous functioning in the geographical area where the administrative action is realised according to Art. $17 \mathrm{~d}$ ). These conditions are verified by the administrative organs, as well as the courts ex officio. As NGOs only have standing if an Act or Government decree confers it to them, there will of course be further "battles" in this field, as there have been over the past decades (Rozsnyai, 2014). Apart from environmental cases in Hungary, this possibility is scarce, for example, in cases in connection with the protection of non-smokers and consumers.

Of course, collective litigation is made possible not only through the rules of standing. The rules of the joinder, the institution of model procedure, the compulsory common representation of at least five claims submitted together, as well as special means for notifying through the administrative organ when the public is affected by the case.

Besides the rules of standing, the CACP had to give answers to these questions of objective protection, which was not an easy undertaking. The Hungarian Basic Law does not contain a specific disposition on the function of administrative justice, it only states that courts decide on the legality of administrative acts. Another obstacle was the system which developed in the last 25 years, deeply rooted in civil procedural rules and principles. This system could not be altered from the bottom to the top through the introduction of an investigative system, as most administrative judges were clearly against such a great change. So the CACP had to find another way to give more room to the constitutional role for controlling the legality of tribunals. It declares on the one hand the duty of effective protection in Art. 2, and places the principle of investigation as an ancillary principle beside the principle of procedural autonomy of the claimant. Flowing from this, the CACP poses several ex officio duties on the tribunals, including grounds which have to be respected ex officio, and the duty of the court to take evidence ex officio. 


\section{Strengthening of the powers of administrative tribunals}

\subsection{First developments: interim relief}

Traditionally, the administrative judge had no power to impose an obligation on the administration (Sommermann, 2018, pp. 1749-1752). In this regard, the concept of sovereign immunity prevailed. However, if the court can only grant protection with its final decisions, that will not be effective. As formulated in Recommendation Rec (2004)20 of the Committee of Ministers of the Council of Europe to member states on judicial review of administrative acts (adopted by the Committee of Ministers on 15 December 2004 at the 909th meeting of the Ministers' Deputies) in connection with the effectiveness of judicial protection: "The tribunal should be competent to grant provisional measures of protection pending the outcome of the proceedings." It is thus very important to give the court sufficient means to preliminarily stop administrative action until the delivery of the judgment. The forerunner of the strengthening of powers therefore stemmed from the field of immediate or preliminary protection against the administration. The Factortame jurisdiction [The Queen v Secretary of State for Transport, ex parte: Factortame Ltd and others (C-213/89, EU:C:1990:257); Zuckerfabrik Süderdithmarschen AG v Hauptzollamt Itzehoe and Zuckerfabrik Soest GmbH v Hauptzollamt Paderborn (C-143/88 and C-92/89, EU:C:1991:65); or Atlanta Fruchthandelsgesellschaft $\mathrm{mbH}$ and others v Bundesamt für Ernährung und Forstwirtschaft (C465/93. EU:C:1995:369)] was a landmark in this regard, which led to the end of the principle of sovereign immunity in several aspects in member states like Great Britain, Germany, Italy (Eliantonio, 2008, pp. 235-253) and at the European level [see e.g. Council of Europe, Committee of Ministers: Recommendation R (89) 8 on provisional court protection in administrative matters and Recommendation R (2003) 16 on the execution of administrative and judicial decisions in the field of administrative law]. We can also trace this development in France and in several Eastern European countries. The French practice did not consider it possible in the "contentieux pour excès de pouvoir" for a long time to impose obligations for the new procedure or to give guidance. This approach has gradually changed, and finally, Act $n^{\circ} 2000-597$ of 30 June 2000 established a new system of temporary protection (Sauvé, 2015, pp. 2-4). There are three main types of "référés": the référé-suspension, the application for suspension of enforcement, the référé-liberté, with which to stop the violation of liberty rights, and the référé-mesures utiles, with which any measure preventing the realisation of the administrative decision may be requested [Art. L. 521-1, 2, 3 of the Code de Justice Administrative (CJA)]. ${ }^{6}$ In Germany - which broke away much earlier from the principle of sovereign immunity - the suspensive effect of the claim is the general rule (Hufen, 2013, p. 484), so there were rather contrary developments (e.g. T. Port GmbH \& Co. KG v Bundesanstalt für Landwirtschaft und Ernährung, C-68/95, EU:C:1996:452).

6 Apart from these three main types, there are quite a number of special "référés", e.g. for access to public information or public procurement contracts (Art. L. 551-1 CJA and Art. L. 551-13 CJA). 
Small signs of the emergence of these convergence processes in Hungary could be found in the sectoral rules. They had granted the possibility of imposing "provisional measures" in some cases, like for the payment of social benefits, or the granting of social care services, or the suspension of the mayor from his office during the court procedure. Even against the official judicial viewpoint that the suspension of enforcement is the only possible means of interim protection, some administrative judges tried to widen the options by interpreting the suspension of the enforcement in a broad sense (e.g. Supreme Court, decision No. 5/2010. KJE for the uniformity of law). The CACP sets forth these tendencies with a set of four tools of interim relief, leaning somewhat on the French solution. So, according to the CACP, the court can order suspensory effect to the administrative action, which cannot be performed or have any other effect until the judgement is delivered. Typically, in public service provision disputes and in some environmental cases, the sectoral law provides for the suspensory effect to be activated by the submission of the statement of claim. As the inverse tool to ordering the suspensory effect, in such cases, the suspensory effect may be dissolved partially or fully by the court. There are further cases where ordering or dissolving suspensory effect is not sufficient to provide interim relief: the court may take any measure within the limits of the decision to be adopted in the court procedure to provide protection immediately. The judge therefore has the possibility to order provisional measures, such as making a right denied by the administration available to the plaintiff for the duration of the procedure or ordering that the administration pay back a sum already executed. The taking of evidence in advance is the fourth tool completing the system. When deciding on granting interim relief, the judge has to ponder periculum in mora and strike a fair balance between private and public interests.

\subsection{Enforcement of decisions}

The weakening of sovereign immunity also led to more powers for the administrative judge in regard to the enforcement of their judgements: in order to secure the closure of the administrative procedures ordered by the administrative tribunals within a reasonable time, sanctioning the administration for failure to respect court decisions became possible in various countries. There are two main types of judicial decision where court enforcement mechanisms do not work: judgements ordering the repeating of procedures and omission judgements, according to which the administrative organ has to fulfil the obligations stated to be omitted by court. The judgments in supervisory procedures often belong to this category too, as specialized forms of annulment or omission judgments, as well as when ordering the calling of the meeting of an organ of the professional body.

In Hungary, until 2018 there were only tools for protection against omissions in the field of judicial decisions ordering the reiteration of authoritative procedures. These were lengthy and complicated procedures, to be led on at least two levels. Moreover, the judiciary held that the system of separation of powers did not allow the court to impose obligations on the authorities beyond 
the conduct of the new procedure. Judges considered that they could not give a deadline for fulfilling the obligation because this way, they would harm the decision-making autonomy of the public administration. Without a deadline, it was not possible to enforce these decisions. The tribunal had no means to enforce its decision or to sanction the non-fulfilment of the judgment.

A separate chapter deals with these problems in the CACP, Chapter XXVI entitled "the procedure to enforce compliance with a judgment ordering a new procedure or establishing failure to act". According to its rules, the court will have several possibilities, if the claimant or the interested person signals the non-fulfilment of its judgment. After requesting clarification from the administrative organ, if this is not satisfactory or none is given, the court can impose a fine on the administration, which is much higher than the procedural fine, up to HUF 10 million (approx. EUR 30,000). This fine is not the only tool for achieving fulfilment of the judgment: the court may also order another administrative organ or, depending on the type of omission, the supervisory authority to perform the duty instead. If these tools are of no use, the court can order provisional measures until the administrative organ fulfils the obligations which arise from the judgement. In the case of a repetitive omission, issuing the leader of the administrative organ with a procedural fine is also possible, which can be an effective measure against the obstruction of administration (see the Appendix, on the procedure to enforce compliance with a judgment ordering a new procedure or establishing failure to act).

Returning to judgements annulling administrative action, their implementation is not only supported by the above tools. It is of utmost importance to have a court judgment which makes clear to the public administration what its obligations are regarding the procedure to be conducted after the judgement. If the new administrative action does not follow these instructions, the court is conferred the possibility to reform it as a sanction, even in cases where it is generally not possible to reform.

\subsection{Ius reformandi}

The reformatory power of the tribunal is not easy to fit into constitutional arrangements as it goes beyond the traditional concept of the separation of powers. When annulling an administrative act, the need to repeat the administrative procedure emerges in order to produce a new administrative act, which in a lot of cases leads to the repetition of all the stages of the procedure (appellate procedure and/or court procedure) after the first instance administrative procedure. It is thus the time pressure which results in a change in the perception of amending judgments. A timely completion of the merits of the procedure can only be achieved by the ius reformandi, and thus the legislator is increasingly using this solution. So we see the power of courts to reform administrative decisions more and more frequently, as in the case of French, Slovenian, and to some extent in German courts, to name just a few. ${ }^{7}$

7 Of course there are single countries where the ius reformandi was to some extent introduced much earlier, like in Austria for decisions without discretion (Olechowski, 2018, p. 1113.) or in Hungary until 1949 and as an exceptional possibility from 1972 on. The ius 
The concept of the CACP was that the various types of administrative action have to be treated differently. Regarding the determination of administrative action through statutory law, there is a constant interaction of the legislative, executive and judicial powers. Often the legislator allows the executive branch more freedom and discretion, which allows the administrative body, on the basis of the same statutory facts, to come to different decisions. As life gets more complicated and technicised, legislation provides the authorities with very broad discretion in order to ensure that conflicts of interest are resolved. This is particularly the case in multipolar administrative legal relationships, among which plant licensing cases are most in the focus. In the course of the procedures, technical and architectural questions, as well as those relating to the protection of landscape, the environment and health, or employment and economic growth become relevant and the administration must strike a fair balance between these interests. It needs to examine and consider a great number of factors, and in the majority of cases, this consideration requires special expertise. The legislator can only finally determine the decision of the administration: it is possible to prescribe the result to be achieved, but not the concrete conditions of the decision. This is due to the level of complexity which causes legal regulations to only refer back to technical standards, professional rules and other, non-legislative rules. In these cases, administrative organs thus choose the solution they deem optimal out of several legitimate alternatives. Judicial review must be guaranteed against all types of administrative action; however, given these differences, the power of courts will also vary to some extent. Without going into questions of judicial deference, which is also an important issue in Hungary (Kovács and Varju, 2014, pp. 202-207), it is obvious that even if there is no discretion accorded to the administration, in many constellations, amendments might also be hindered in practice depending on the merits of the case, as courts can only amend some decisions through lengthy and complicated evidence procedures, such that the benefit of a reduction in the number of redress procedures would disappear. Also, the need for further redress would emerge and produce additional remedies. On the one hand, there are administrative decisions which are totally bound by law: if conditions are fulfilled, there is a single administrative act to be taken. There are cases - quite a number of them - where questions of the merits only touch on the interpretation of the law. As it is ultimately up to the courts to answer these questions, there are a lot of constellations where the court can reform administrative acts without touching on the discretional powers of the administration.

Given all these considerations, the Hungarian CACP puts a soft obligation on courts to amend unlawful administrative acts. This obligation is "soft", as it is the court which has to evaluate whether the nature of the case makes it possible to amend a decision. This solution can avoid causing harm to the powers of administration and consequently, the doctrine of separation of powers. To help courts, special cases are mentioned where no amendment is possible. On the one hand, the gravest forms of illegality cannot be healed, such as

reformandias a general possibility or even as a duty of the court however is rather a new phenomenon. 
the nullity or completely erroneous grounds of the administrative action contested. On the other hand, the CACP lists some cases where the nature of the case is deemed to not allow reformation: besides normative acts, this is the case for administrative acts relating to a payment affecting the budget based on exercising equity. To ensure timeliness, the other two positive criteria for amendment, besides the nature of the case allowing for it, are that the facts are properly clarified and the legal dispute may be ultimately settled on the basis of the data available (see the Appendix).

In the majority of their cases, Hungarian tribunals already had a reformatory power before 2018, but they rarely made any use of it. Thus, the CACP also creates an institution called "amending the amount of a payment obligation", leaning on the German solution in order to help make use of the reformational powers [Art. 113 (2) sentences 2 and 3 of the German Administrative Court Order]. According to Art. 91 of the CACP, the court can amend the administrative act without establishing the concrete amount of the payment obligation by providing accurate guidance in the judgment as to its calculation. Upon the judgement, the administrative organ promptly calculates the exact amount of the payment obligation (not being contested or not contested successfully by the parties) and the amount calculated becomes part of the judgment upon the court's approval. The time limit for submitting an application for legal remedy shall start on the day following the order approving the amount of the payment obligation. This tool is very helpful, for example, in tax cases, where the amount of tax due has to be fixed with a software not available to courts, or in the case of fines having to be calculated with complicated formulas.

\subsection{Ex-post correction of errors through the administration in the course of the court procedure}

Another procedural constellation, which raises questions regarding the merging of powers, is the administration's ability in numerous countries to correct errors of its action even if there is a court procedure initiated against it. For example, the German Administrative Procedure Act allows the subsequent amendment of the justifications and the replacement of the remaining procedural acts during the court procedure. An instrument similar to this is the Dutch institution of the "administrative loop" ("bestuurlijkelus"), which provides an opportunity for the administrative court to give the case back to the administration in the course of the proceedings in order to remedy, where possible, the offenses in the case (GALA Art. 8:51a). There is no doubt that these opportunities raise many questions due to their novelty. The Dutch solution was, for example, adopted by Belgium, but the Constitutional Court of Belgium annulled the relevant legislation in its decision No. 74/2014 of May 8 2014. The Court deemed the approach unconstitutional because of the violation of the principles of independence and impartiality of the court, the right to appeal and the right of defence. Similar German legislation has led to a procedure of non-fulfilment of obligations before the Court of Justice of the European Union resulting in the European Commission v Federal Republic of Germany case (C-137/14, EU:C:2015:683). These arrangements are neverthe- 
less necessary given that the overall tendency is to cut back inner-administrative review procedures. The possibility of self-control of the administration has to be ensured too, as this often enables the final resolution of a case in a much less complicated manner than do court procedures.

Promptly reaching the final decision in a case is another motivation underlying the current tendency to promote mediation in administrative court procedures. At first, one would think that the doctrine of separation of powers is opposed to mediation: how could the administration and the other party "bargain" over the legality of an administrative action? But again, this is far from being the case: within the scope of its powers, especially when the review concerns discretionary administrative action, the public administration can amend or take back its decision or agree to modify a contract, which can tackle the situation in a mutually beneficial and lawful way. This is especially true for multilateral legal relationships. Reaching a settlement is much more satisfactory than repeating the procedure after an annulment.

Of course, mediation needs proper rules within court procedures. Thus, in Chapter XI, the Hungarian CACP gives a set of rules for mediation and settlement, and tries to foster its use in several ways. The court has the obligation to take all possible opportunities to reach a peaceful settlement of the case. Albeit, to ensure the legality of the administration, it is up to the court to decide whether the case is apt for mediation at all, and whether the settlement reached is lawful.

\section{Handling procedural errors}

The broadening of access to courts and the strengthening of the power of courts brought about the introduction of preclusion rules. These raise new questions which also touch on the principle of separation of powers. Among the different types of preclusion rules we will now focus only on the question of the consequences of procedural errors. The assessment of procedural violations by courts is restricted throughout Europe, either through the selfrestraint of the courts or through the legislature's actions. Of course, it is necessary to weigh the procedural rules. Public interest and the interests of external legal entities and parties often require restrictions. According to the settled concept of procedural law being subordinated to material law (e.g. in Germany: Schmidt-Aßmann, 2006, p. 356), procedural infringements should be assessed only in situations which resulted in the procedural safeguard not actually providing any protection to the party. The "requirement of a causal link" thus states that if a decision is to be successfully challenged on the basis of a procedural error, there must, in the circumstances of the case, be a definite possibility that the contested decision would have been different without the procedural error. This requirement can frequently, if not always, be found in the procedural law of administrative courts throughout Europe, for example, in Art. 46 of the German Administrative Procedure Act and in the jurisdiction of the ECJ (Barabás, 2015, pp. 424-434). 
Procedural guarantees gain even more importance, and the principle of good administration evolves to a right (or set of rights) enshrined in the European Charter of Human Rights and in national constitutions or procedural codes. This is the case in Hungary too (Art. XXIV of the Basic Law of Hungary and Art. 1 of the Code of General Rules of Administrative Procedure). Thus, this concept is becoming increasingly in doubt and we see a new differentiation emerging beyond the procedural errors and vices of substantive law. Procedural errors can be so serious that they must not be subject to the requirement of a causal link, whereas less significant procedural errors continue to be so. This differentiation can be seen in the Gemeinde Altrip v. Land Rheinland-Pfalz decision of the ECJ (C-72/12, EU:C:2013:712), as well as in the case law of the French Conseil d'État [Danthony et autres (FR:CEASS:2011:335033.20111223) or Luc-en-Provence (FR:CESSR:2014:356142.20140324)]. Consequently, challenging an administrative act can sometimes be successful, even if the causal link is missing, if the case involves a serious infringement of an important procedural right.

The Hungarian CACP also tried to reflect the constitutional importance of the right to good administration. The causation link theory - as developed by the judiciary - is still the general rule, but with exceptions. Art. 88 states that the court shall dismiss the claim if the procedural infringement does not have a relevant impact on the outcome of the case, but at the same time, according to Art. 92, it is obligatory to annul the administrative act if the infringement caused by the violation of substantial rules of the preceding administrative procedure cannot be remedied in the court procedure. Of course, it comes back to the courts to define which rules are to be regarded as substantial rules. Here they have to ponder the different aspects of the right to good administration as enshrined in the Charter and in the Hungarian Constitution, and as further developed by the Act on Administrative Procedure (see the Appendix on typical judgments).

The weight of procedural errors and the connected preclusion rule is only one question of the rule of law to consider now at the dawn of the 21st Century. There are other questions relating to preclusion rules, such as the procedural preclusion of persons not raising their objections in the administrative procedure, or substantive preclusion rules banning evidence and facts from administrative court procedures not referred to in the administrative procedure. These preclusion rules also are based on the idea that administrative procedures, if conducted properly, also protect the rights and interests of persons affected by the administrative action (Schmidt-Aßmann, 2006, p. 361). However, a separate study would be required to address this point. 


\section{References}

Barabás, G. (2015). Doctrines of Legal Consequences of Administrative Procedural Irregularities. In B. Gerencsér, L. Berkes and A. Zs. Varga, eds., Current Issues of the National and EU Administrative Procedures (the ReNEUAL Model Rules). Budapest: Pázmány Press, pp. 419-436.

Barabás, G. and Nagy, M. (2011). Le contentieux des contrats publics en Europe Hongrie. Revue Française d'Administration Publique, (1), pp. 47-53.

Eliantonio, M. (2008). Europeanisation of Administrative Justice? Amsterdam: Europa Law Publishing.

Fábián, A. and Hoffman, I. (2014). Local Self-Governments. In A. Patyi and A. Rixer, eds., Hungarian Public Administration and Administrative Law. Passau: Schenk Verlag, pp. 320-349.

Hoffman, I. and Rozsnyai, K. (2015). The Supervision of Self-Government Bodies' Regulation in Hungary. Lex Localis: Journal of Local Self-Government, 13(3), pp. 485-502.

Hufen, F. (2013). Verwaltungsprozessrecht. München: C.H. Beck.

Kovács, A. Gy., Tóth, T. and Forgács, A. (2016). The Legal Effects of European Soft Law and Their Recognition at National Administrative Courts. Elte Law Journal, (2), pp. 53-71.

Kovács, A. Gy. and Varju, M. (2014). Hungary: The Europeanization of Judicial Review. European Public Law, 20(2), pp. 195-226.

Olechowski, T. (2018). 28 Geschichte der Verwaltungsgerichtsbarkeit in Österreich. In K.P. Sommermann and B. Schaffarzik, eds., Handbuch der Geschichte der Verwaltungsgerichtsbarkeit in Deutschland und Europa. Berlin-Heidelberg: Springer, pp. 1099-1130.

Patyi, A. (2002). Közigazgatási bíráskodásunk modelljei [Models of our administrative justice]. Budapest: Logod.

Proposal of the European Commission of 11 April 2018 for a Directive of the European Parliament and of the Council on representative actions for the protection of the collective interests of consumers [COM(2018) 184 final]. At <https://ec.europa.eu/info/sites/info/files/proposal_for_a_directive_on representative_actions_for_the_protection_of_the_collective_interests_of consumers_0.pdf $>$, accesse 27 October $20 \overline{18}$.

Rozsnyai, K. (2018). 43 Geschichte der Verwaltungsgerichtsbarkeit in Ungarn. In K.P. Sommermann and B. Schaffarzik, eds., Handbuch der Geschichte der Verwaltungsgerichtsbarkeit in Deutschland und Europa. Berlin-Heidelberg: Springer, pp. 1569-1599.

Rozsnyai, K. (2014). Public Participation in Administrative Procedures: Possibilities and Recent Developments in Hungary. Curentul Juridic, (3), pp. 50-66. At <http://revcurentjur.ro/old/arhiva/attachments_201403/ recjurid143_5A.pdf>, accessed 27 October 2018.

The recommendation of the European Commission of 11 June 2013 on common principles for injunctive and compensatory collective redress mechanisms in the Member States concerning violations of rights granted under Union Law (2013/396/EU). At <https://eur-lex.europa.eu/legal-content/EN/TXT/HTML/?u ri=CELEX:32013H0396\&from=EN>, accessed 27 October 2018. 


\section{Appendix}

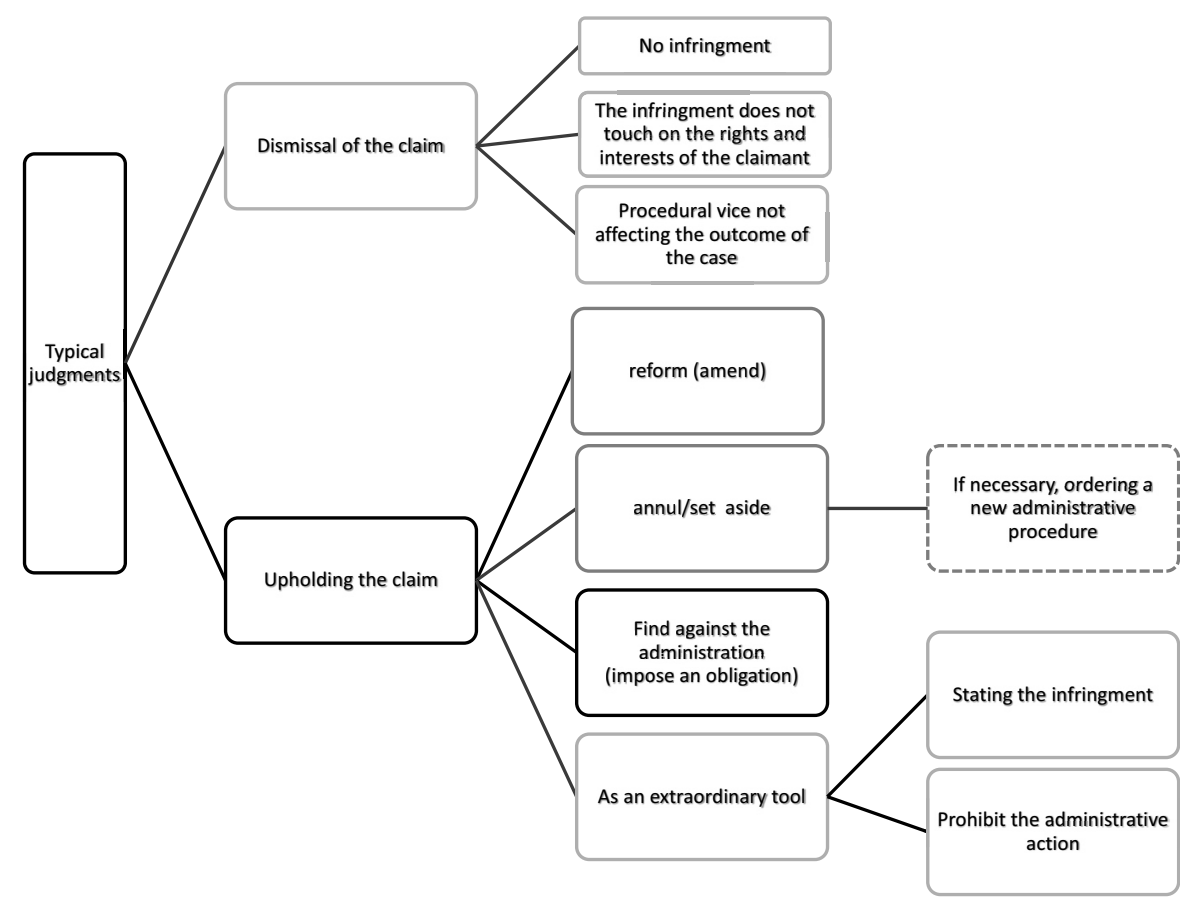

\section{lus reformandi}
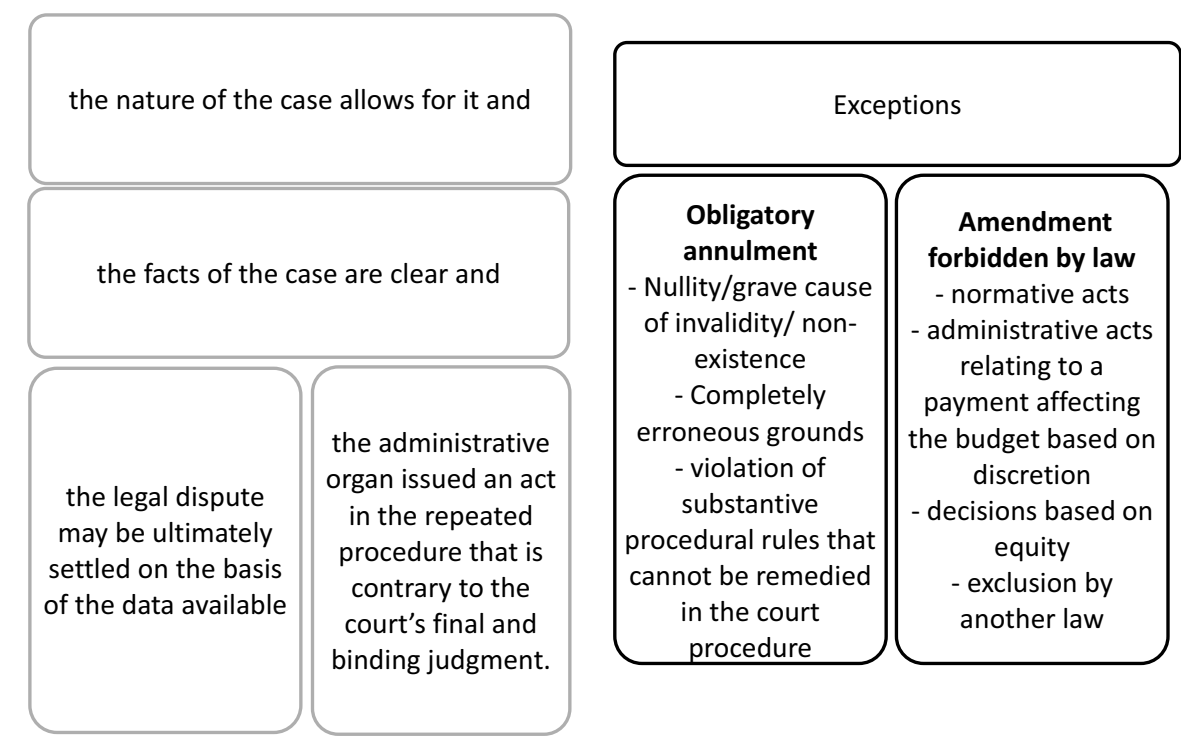
The procedure to enforce compliance with a judgment ordering a new procedure or establishing failure to act

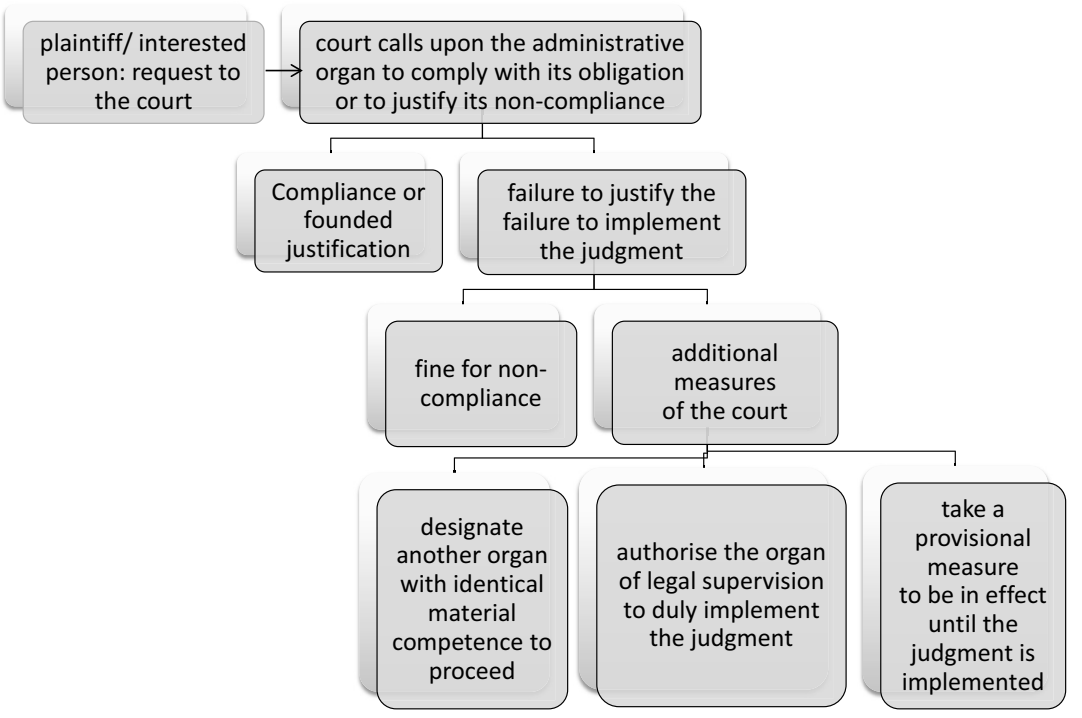

